\title{
SLC31A1 wt Allele
}

National Cancer Institute

\section{Source}

National Cancer Institute. SLC31A1 wt Allele. NCI Thesaurus. Code C127859.

Human SLC31A1 wild-type allele is located in the vicinity of 9q32 and is approximately 43 $\mathrm{kb}$ in length. This allele, which encodes high affinity copper uptake protein 1 , is involved in transmembrane copper ion transport. 